\title{
GLUT4 JARINGAN ADIPOSA FUNGSI DAN DISFUNGI
}

\author{
Henry C. P. Kaunang \\ Sunny Wangko
}

\author{
Bagian Anatomi-Histologi Fakultas Kedokteran \\ Universitas Sam Ratulangi Manado \\ Email: henry.kaunang@hotmail.com
}

\begin{abstract}
Following the discovery of insulin nearly a century ago, it has become easier to comprehend the mechanism of this peptide hormone. Insulin activates the phosphorylation of tyrosine kinase and consequently triggers the intracellular signals that regulate most of the processes within the cells of our body. In order to maintain the glucose homeostasis, insulin reduces glucose production in the liver and increases glucose uptake into muscles and adipose tissues by escalating the glucose transporter 4 (GLUT4) translocation from within the cells to the outer part of the membranes. Many efforts have been put forth out of the curiosity of scientists to provide answers, but further exploration of insulin receptor signaling pathways and junctures in trafficking has made it clear that many questions are left unanswered. Interestingly, these questions are being more focused on; hence, the functional molecules, in particular those that were required for insulin signaling cascades and junctures of GLUT4 vesicle trafficking have become the interest for further research. The degenerative diseases with broad complications due to the impaired of glucose homeostasis preserved by insulin have become the main target in developing a therapy or even prevention. Many joint efforts of scientists using numerous research methods offer great expectations for better comprehension of regulating the GLUT4 vesicle trafficking.
\end{abstract}

Keywords: insulin stimulation, adipose tissue, GLUT4 trafficking

\begin{abstract}
Abstrak: Dengan ditemukannya insulin hampir seabad lalu, semakin banyak yang diketahui tentang mekanisme kerja hormon peptida ini. Insulin memfosforilasi tirosin kinase sekaligus juga mengaktifkannya sehingga memicu kaskade sinyal intrasel yang meregulasi sebagian besar proses di dalam sel. Untuk mempertahankan homeostasis glukosa, insulin menekan produksi glukosa di hepar dan meningkatkan ambilan glukosa pada jaringan otot dan adiposa dengan meningkatkan translokasi transporter glukosa 4 (GLUT4) menuju permukaan membran plasma. Telah banyak usaha yang dilakukan untuk menjawab keingin-tahuan para ilmuwan, namun semakin menggali ke dalam kompleksitas molekular lintasan sinyal reseptor insulin dan tahapan-tahapan proses trafficking, semakin banyak pertanyaan yang muncul ke permukaan. Hal ini menarik untuk dikembangkan karena spesifitas molekul fungsional yang dibutuhkan untuk kaskade sinyal insulin dan tahapan trafficking vesikel GLUT4 dapat menjadi titik tangkap untuk penelitian. Penyakit degeneratif dengan komplikasi yang luas akibat terganggunya homeostasis glukosa oleh insulin menjadi sasaran utama dalam pengembangan terapi penanganan atau bahkan pencegahan. Upaya para peneliti dengan penggunaan beragam metode penelitian sangat diharapkan mampu memberikan secercah cahaya dalam memahami regulasi insulin dalam trafficking vesikel GLUT4
\end{abstract}

Kata kunci: stimulasi insulin, jaringan adiposa, trafficking GLUT4 
Secara global dewasa ini insidens diabetes melitus semakin meningkat, dimana $90 \%$ di antaranya adalah diabetes melitus tipe 2 (DMT2). Pada tahun 2000 diperkirakan 150 juta penduduk dunia menderita DMT2, dan akan menjadi dua kali lipat, yaitu sekitar 300 juta, pada tahun 2025. ${ }^{1}$ DMT2 ditandai antara lain oleh terganggunya kesanggupan insulin untuk menstimulasi ambilan glukosa ke dalam sel dan menekan produksi glukosa hati. Dengan kata lain sekresi insulin yang ada (mungkin berlebihan) gagal untuk mengompensasi resistensi insulin pada jaringan perifer. ${ }^{2-4}$

Dalam keadaan puasa hati menghasilkan glukosa melalui glukoneogenesis dan glikogenolisis. Insulin bekerja mempertahankan homeostasis glukosa dengan menekan proses glukoneogenesis dan glikogenolisis tersebut. Selain itu insulin meningkatkan ambilan glukosa oleh jaringan perifer, terutama jaringan adiposa dan otot rangka, dengan bantuan glucose transporter (GLUT). ${ }^{3,5,6}$ Dalam hal ini terjadi transpor secara fasilitatif dimana glukosa dapat berdifusi secara pasif ke dalam jaringan adiposa tanpa memerlukan ATP, yaitu dengan menggunakan GLUT4. 3,4,7,8

Pada permukaan sel, GLUT4 memfasilitasi difusi pasif glukosa sirkulasi bila konsentrasi glukosa menurun pada jaringan otot rangka dan adiposa. ${ }^{9}$ Terjadinya disfungsi GLUT4 baik dalam keadaan basal atau terhadap stimulasi insulin akan mengarah ke resistensi insulin, dan selanjutnya DMT2. ${ }^{10}$ Menariknya, dalam proses metabolisme lipogenesis yang menggunakan glukosa sebagai substrat, ternyata GLUT4 berespon sangat baik terhadap insulin, bahkan diregulasi oleh kaskade sinyal insulin melalui lintasan phosphatidylinositol 3-kinase (PI3K). Dengan stimulasi insulin, kerja GLUT4 untuk memfasilitasi masuknya glukosa ke dalam jaringan adiposa ternyata dapat meningkat sampai 20-30 kali lipat dari keadaan basal. ${ }^{9}$ Tanpa adanya stimulasi insulin, GLUT4 disekuestrasi di dalam sel jaringan otot rangka dan adiposa dalam bentuk vesikel lipid berlapis ganda. ${ }^{10}$

Berbagai keadaan patologik dapat mempengaruhi kerja GLUT4, yang mencakup kompartemen penyimpanan intrasel, eksositosis, reseptor insulin, translokasi GLUT4, docking dan fusi GLUT4 ke membran plasma, endositosis dan transit interendosomal, serta aktivasi GLUT4. Kesemuanya ini berperan penting dalam mutu kerja GLUT4. Dalam proses-proses di atas terdapat berbagai rangkaian reaksi biokimiawi dengan melibatkan berbagai jenis senyawa kimia yang kesemuanya masih kurang dipahami. ${ }^{5}$ Untuk dapat mengoptimalkan kerja GLUT4 sebagai salah satu usaha mempertahankan homeostatis glukosa, maka diperlukan studi dan penelitian lanjut.

\section{TRANSPORTER GLUKOSA 4 (GLUT4)}

Transpor glukosa fasilitatif dimediasi oleh famili GLUT, yang membentuk poripori akueus menembus membran plasma sehingga glukosa dapat melewati membran secara pasif. GLUT hanya dapat mentranspor glukosa ke dalam sel (satu arah/uniport) bila terdapat perbedaan gradien konsentrasi glukosa. Protein transmembran terglikosilasi dari famili GLUT tersusun oleh 12 rentangan pada membran plasma dengan kedua terminal amino dan karboksil berada dalam sitosol. $^{7,9}$

\section{GLUT4 peka insulin}

GLUT4 manusia terdiri dari 509 asam amino, dan menunjukkan kemiripan asam amino sekitar $60 \%$ dengan isoform GLUT1 dan GLUT3. GLUT4 merupakan GLUT yang peka terhadap insulin, serta diekspresi pada membran plasma dan organela dari otot rangka, otot jantung dan jaringan adiposa untuk pengambilan glukosa yang diregulasi insulin. GLUT4 bereaksi terhadap peningkatan kadar insulin plasma secara cepat dengan menghasilkan peningkatan transpor glukosa 20-30 kali lipat. Tanpa adanya stimulasi insulin atau olah raga, 90\% GLUT4 disekuestrasi di dalam sel jaringan otot rangka dan adiposa dengan bentuk vesikel bermembran lipid berlapis ganda. Pada permukaan sel, GLUT4 memfasilitasi difusi pasif glukosa sirkulasi bila konsentrasi glukosa dalam jaringan otot rangka dan adiposa menurun., 3 


\section{Protein GLUT4 dan vesikel pengangkut}

GLUT4 dikemas dalam struktur tubulovesikular pada regio perinuklear dan vesikel-vesikel kecil yang tersebar dalam sitoplasma (vesikel penyimpan GLUT4, GLUT4 storage vesicles, GSVs). GLUT4 regio perinuklear terlokalisasi dalam endosom dan struktur jaringan trans-Golgi (trans-Golgi network, TGN). Dengan adanya stimulasi insulin, GSVs dimobilisasi ke permukaan sel sehingga terjadi peningkatan GLUT4 pada membran plasma dan penurunan kandungan GLUT4 dalam vesikel sitosolik, sedangkan vesikel GLUT4 regio perinuklear relatif tidak berubah. ${ }^{5,11}$

\section{SIKLUS TRANSLOKASI GLUT4}

Aktivasi reseptor insulin (insulin receptor, IR) memicu serangkaian kaskade fosforilasi yang menyebabkan eksositosis vesikel GLUT4. Lintasan sinyal insulin meliputi docking substrat reseptor insulin (insulin receptor substrate, IRS) pada reseptor insulin, aktivasi PI3K yang mengarah ke pembentukan phosphatidyl-inositol 3,4,5-trisphosphate (PI3,4,5-P3) pada membran plasma, yang selanjutnya memediasi aktivasi protein kinase $\mathrm{B}(\mathrm{PKB}) /$ Aktin (Akt) dan protein kinase $\mathrm{C}$ atipikal (aPKC). $3,5,11,12$

\section{Penyimpanan GLUT4 intrasel.}

\section{Kompartemen penyimpanan GLUT4}

Pada keadaan basal, sebagian besar GLUT4 terdistribusi pada sistem endomembran. Setelah translokasi yang distimulasi insulin, GLUT4 terlepas dari membran plasma dengan endositosis, dan kembali ke kompartemen endosom dan TGN. ${ }^{12}$

\section{Insulin-regulated amino peptidase (IRAP)}

IRAP merupakan protein utama yang berko-lokalisasi dengan GLUT4 pada vesikel penyimpanan yang peka terhadap insulin. IRAP berperan penting dalam siklus translokasi GLUT4 dan merupakan target kaskade sinyal insulin dimana GLUT4 akan terikat pada GSVs untuk menjalani eksositosis menuju membran plasma. ${ }^{5,12}$

\section{GLUT4 Targeting Motifs.}

Pemahaman mekanisme untuk targeting GLUT4 dalam kompartemen intrasel dapat memberikan gambaran mengenai mekanisme molekular insulin dalam memobilisasi vesikel GLUT4. Terminal amino targeting motif (Phe-Gln-Gln-Ile) FQQI merupakan unsur penting untuk sekuestrasi intrasel GLUT4. Demikian pula terminal karboksil berperan penting dalam lokalisasi intrasel dari GLUT4. Setelah recycling dari permukaan sel kembali menuju TGN, GLUT4 menjalani proses sortir. ${ }^{12,13}$

\section{Eksositosis}

\section{Struktur dan fungsi reseptor insulin}

Reseptor insulin adalah famili reseptor transmembran yang tersusun dari 51 asam amino dengan dua ikatan disulfida heterodimer berupa subunit $\alpha$ dan $\beta$, yang membentuk struktur hetero-tetrametrik $\alpha_{2} \beta_{2}$. Proses stimulasi insulin diinisiasi ketika hormon ini terikat dengan afinitas tinggi pada reseptornya (dua subunit- $\alpha$ ekstrasel) yang merupakan aktivasi kaskade sinyal insulin. Insulin kemudian memicu aktivasi tirosin kinase intrinsik pada subunit- $\beta$. Selanjutnya subunit- $\beta$ menjalani serangkaian reaksi transotofosforilase intermolekular yang memicu beragam lokasi fosfotirosin untuk berlangsungnya kaskade sinyal insulin pada beberapa jenis protein, terutama IRS. $^{4,12}$

\section{Kompleks sinyal jaringan pada reseptor insulin}

Reseptor insulin memfosforilasi beberapa protein scaffolding yang tidak memiliki aktivitas enzimatik intrinsik. Fosforilasi tirosin yang tergantung insulin dari IRS nantinya merekrut berbagai protein efektor untuk kaskade lanjut. Terdapat sejumlah protein scaffolding untuk kaskade lanjut dari reseptor insulin yang teraktivasi; termasuk disini empat famili IRS 1-4, Gab1, Shc, SIRPS, Cbl, dan protein adaptor yang mengandung $\mathrm{PH}$ dan SH2 (APS). Proteinprotein ini berfungsi sebagai lokasi docking untuk efektor kaskade lanjut, termasuk 
subunit regulatoris p85 dari PI3K kelas $1 \mathrm{~A} .{ }^{12}$

\section{Translokasi GLUT4 dan PI3K.}

Di antara isoform PI3K, enzim kelas 1A berimplikasi langsung pada sinyal yang mengarah pada translokasi GLUT4 jaringan adiposa. PI3K kelas $1 \mathrm{~A}$ tersusun atas subunit regulatorik p85 dan subunit katalitik p110, dan berfungsi mengatalisis fosforilasi pada posisi D3. Subunit p85 mengikat residu fosfotirosin dan meregulasi aktivitas katalitik dari subunit p110. Interaksi ini nampaknya memberikan efek ganda yaitu mengaktivasi PI3K. Kemudian mengarahkannya ke lokalisasi substrat PI(4,5)P2 pada membran plasma yang dibutuhkan untuk kaskade sinyal selanjutnya, yaitu stimulasi protein kinase $\mathrm{B}$ (PKB) dan protein kinase $\mathrm{C}$ atipik (aPKC). Peningkatan lokal PI(3, 4,5)P3 pada membran memicu rekrutmen dan penjangkaran molekul sinyal kaskade lanjut yang mengandung homolog plekstrin $(\mathrm{PH})$. Interaksi ini dibutuhkan untuk kelanjutan stimulasi sinyal yang tergantung insulin untuk translokasi GLUT4. Lanjutan sinyal PI3K berlangsung melalui aktivitas inositol 5 fosfatase tipe II (SHIP2), yaitu fosfatase yang mengeluarkan ikatan 5 fosfat dari $\mathrm{PI}(3,4,5) \mathrm{P} 3$. $^{5,12}$

\section{Protein kinase $B$ dan atypical protein kinase $C$.}

Insulin dengan cepat mengaktivasi PKB serin/treonin (juga disebut Akt=Aktin). Hal ini berlangsung melalui aktivitas PI3K dan PI3,4,5P3, yang merekrut PKB ke membran plasma melalui interaksi spesifik dengan terminal PH. Pada membran plasma, PKB diaktivasi ketika dua residu (treonin 308/ T308 dan serin 473/S473) terfosforilasi. Mekanisme aktivasi PKB secara umum mendukung peran fungsi PKB dalam translokasi GLUT4 yang distimulasi insulin, walaupun penelitian lain melaporkan bukti yang berlawanan. Fosforilasi regulatorik pada kinase ini nampaknya menginduksi perubahan konformasional yang mengaktivasi aPKC. Aktivasi aPKC juga dapat berlangsung melalui otofosforilasi dan bebas dari inhibisi pseudosubstrate. ${ }^{12}$

\section{Alternatif lintasan sinyal insulin.}

Penelitian menunjukkan bahwa kandidat kaskade sinyal kedua bekerja secara fungsional dalam domain mikro lipid raft kaya caveolin. Terdapat dua jenis protein adaptor yaitu adapter protein containing a $\mathrm{PH}$ and SH2 domain (APS) dan adenylate cyclase associated protein (CAP) untuk mengaktivasi reseptor insulin. APS juga merupakan substrat reseptor insulin; APS terfosforilasi memfasilitasi fosforilasi CAP oleh reseptor insulin. Mutasi CAP menghambat translokasi GLUT4 yang distimulasi insulin dan ambilan glukosa, tanpa mempengaruhi lintasan sinyal PI3K. Penelitian lain menunjukkan bahwa terdapat implikasi TC10 dalam translokasi dan ambilan glukosa yang terinduksi syok. ${ }^{12}$

\section{Peran sistem membran dan sitoskeletal}

Aktin kortikal selular ditemukan dalam dua bentuk: aktin globular monomerik (aktin-G) dan aktin filamen (aktin-F). Pada adiposit, insulin menyebabkan pembentukan aktin-F. Filamen aktin ini berperan penting dalam rekrutmen eksositosis yang terinduksi insulin, namun tidak pada endositosis GLUT4. Terdapat dua hipotesis mengenai peran aktin dalam hal ambilan glukosa. Yang pertama adalah insulin menyebabkan remodeling aktin kortikal dan vesikel melalui aktin perifer untuk berfusi dengan membran plasma. Hipotesis kedua menyatakan bahwa filamen aktin berfungsi sebagai "jalan raya", untuk vesikel agar mencapai membran plasma. Nampaknya sinyal insulin yang mengatur aktin kortikal menunjukkan lintasan yang dibutuhkan untuk pergerakan optimal atau fusi vesikel yang mengandung GLUT4 dan membran plasma. Regulasi aktin filamen dicapai melalui protein pengikat aktin dan fosfolipid membran. ${ }^{4}$ Juga terdapat mikrotubulus yang meregulasi endositosis dan eksositosis vesikel GLUT4. ${ }^{12}$

\section{Docking dan fusi}

\section{SNARE protein.}

Oleh adanya stimulasi insulin, vesikel GLUT4 intrasel menuju membran plasma kemudian menyatu dengannya melalui pro- 
ses docking dan fusi. Sebaliknya endositosis vesikel GLUT4 dimediasi oleh interaksi antara vesikel spesifik dan kompleks protein membran plasma yang dikenal sebagai soluble N-ethylmaleimide-sensitive factor atachment protein receptor (SNARE) untuk reseptor SNAP (synaptosomal-associated protein). SNARE vesikel (v-SNARE,) akan mengikat SNARE target membran ( $\mathrm{t}-$ SNARE) beserta sejumlah protein lainnya. Jenis t-SNARE Syntaxin4 dan SNAP23 serta V-SNARE VAMP2 terlibat dalam fusi vesikel GLUT4. Jadi, v- dan t-SNARE merupakan kebutuhan fisiologis minimal untuk terjadinya fusi membran., 2,5,12,14, Protein SNARE membantu demarkasi kompartemen membran yang potensial untuk fusi. Kompartemen membran dan spesifitas fusi sangat penting untuk trafficking GLUT4 selama biogenesis, penyimpanan intraselular, eksositosis dan pengambilannya ke permukaan sel. Selain SNARE terdapat beberapa protein lain yang dapat meregulasi proses fusi dan membantu menjamin spesifitas fusi membran. ${ }^{12}$ Synaptobrevin 2 (VAMP2) dan cellubrevin (VAMP3) merupakan jenis v-SNARE vesikel GLUT4 potensial yang terekspresi pada adiposit, dimana sebagian terlokalisasi dalam kompartemen membran intrasel GLUT4. Keduanya bertranslokasi ke membran plasma setelah stimulasi insulin., ${ }^{5,12}$

\section{Protein terkait SNARE dalam translokasi GLUT4}

Pada studi in vitro, protein neuralspecific syntaxin-binding protein $(\mathrm{nSec} 1)$ berinteraksi kuat dengan syntaxin1 dan berkompetisi dengannya untuk mengikat synaptobrevin2 dan SNAP25. Jadi, nSec1 secara efektif mencegah pembentukan kompleks syntaxin1-synaptobrevin2-SNAP25. Hal ini menunjukkan bahwa protein nSec1 berperan positif selama fusi membran. Analisis struktur kompleks nSec1-syntaxin1 menunjukkan bahwa nSec mempertahankan keadaan inaktif/tertutup dari syntaxin1, sehingga fusi membran dapat berlangsung. Protein nSec1 ini dapat meregulasi keadaan transisi antara konformasi tertutup dan terbuka dari syntaxin $1 .^{12,15}$

Selain itu terdapat peptida pendek yang berikatan dengan asam amino dari mammalia uncoordinated-18 (Munc18), yang menginhibisi kemampuan vesikel GLUT4 untuk berintegrasi pada membran plasma namun tidak menghambat trafficking vesikel GLUT4 menuju permukaan sel. Vesikel GLUT4 akan terakumulasi dibawah membran plasma; hal ini menunjukkan terjadinya inhibisi pada tahap awal proses fusi membran. Dengan kata lain Munc18c berperan positif atau bersifat fasilitatif selama fusi vesikel GLUT4 dengan membran plasma, terutama dengan menjaga syntaxin4 dalam keadaan konformasional untuk berinteraksi dengan synaptobrevin2. Pada keadaan basal, Munc18c berinteraksi dengan syntaxin4 dan menghambat fusi vesikel GLUT4 dengan membran plasma, yaitu dengan cara mempertahankan syntaxin 4 dalam keadaan konformasional tertutup yang inaktif. Setelah stimulasi insulin, Munc18c mengalami perubahan konformasional yang nantinya memfasilitasi interaksi antara syntaxin4 dan synaptobrevin2., ${ }^{2,12}$

Terdapat beberapa jenis protein yang berinteraksi dengan syntaxin4 sebagai komponen regulator lainnya yang diperlukan untuk translokasi GLUT4; salah satunya disebut syntaxin4-interacting protein (synip). ${ }^{4}$ Insulin menyebabkan disosiasi synip dari syntaxin4. Regio terminal karboksil berinteraksi dengan syntaxin4 sedangkan regio terminal amino merupakan lokasi regulatorik insulin untuk disosiasi kompleks synipsyntaxin4. Synip berfungsi sebagai kontrol fusi pada membran plasma. Tanpa adanya stimulasi insulin, synip terikat dan membungkus molekul syntaxin4, sehingga mencegah fusi vesikel nonspesifik. Stimulasi insulin melepaskan synip dan memaparkan syntaxin4, sehingga dapat berinteraksi dengan synaptobrevin $2 .^{12}$

\section{Peran Rab dan ARF dalam translokasi GLUT4}

Protein Rab merupakan cabang terbesar superfamili rat sarcoma protein (Ras) dari protein pengikat GTP kecil. Rab terlokalisa- 
si pada permukaan sitoplasmik kompartemen intrasel dan meregulasi GLUT4. Rab yang terikat GTP berinteraksi dengan protein efektor yang meregulasi beberapa tahap transpor membran, termasuk perlekatan vesikel, motilitas, tethering dan fusi.

Insulin menstimulasi pertukaran nukleotida pada Rab4 dan menyebabkan redistribusi Rab4 dari fraksi mikrosom menuju fraksi sitosolik; hal ini berlangsung secara paralel dengan translokasi GLUT4 menuju permukaan sel. Translokasi GLUT4 terstimulasi insulin juga diinhibisi oleh introduksi peptida yang berhubungan dengan terminal karboksil Rab4, karena bentuk sitosolik protein ini berfungsi sebagai inhibitor dominan bila berada pada kadar yang tinggi. ${ }^{2,3,12}$

Rab5 awalnya dikenali sebagai regulator fusi antara vesikel dan endosom saat awal. Penelitian terkini menunjukkan bahwa insulin dapat menghambat aktivitas Rab5, dengan cara menurunkan tingkat endositosis GLUT4 dan sebagai lokalisasi transporter pada membran plasma. Rab 11 berlokalisasi pada recycling endosom perinuklear dan menunjukkan ko-lokalisasi dengan vesikel GLUT4 dan beredistribusi menuju membran plasma sebagai respon terhadap insulin. ${ }^{12}$

Faktor ribosilasi-ADP (ARF) merupakan subfamili Ras penting lainnya yang terlibat dalam trafficking vesikel. ARF diketahui berfungsi pada tahap awal pertambahan vesikel selama rekrutmen protein pembungkus pada kompartemen membran. Nampaknya satu atau lebih isoform ARF terlibat dalam perjalanan trafficking GLUT4 intraseluler. ${ }^{12}$

\section{Endositosis dan transit inter-endosomal.}

Analisis mikroskop elektron menunjukkan bahwa pada keadaan basal GLUT4 terikat ke membran dan mengalami internalisasi melalui ceruk berlapis clathrin dan caveola. Dinamin GTPase merupakan mole-kul esensial yang berperan penting dalam proses pembentukan vesikel endositik. Dinamin membungkus pangkal vesikel yang mengalami invaginasi dengan konformasi spiral. Hidrolisis GTP menyebabkan perubahan konformasi dinamin sehingga pang- kal vesikel yang mengalami invaginasi bebas terlepas. Pembentukan vesikel yang tergantung dinamin merupakan target regulasi insulin untuk endositosis GLUT4. ${ }^{2,12}$

\section{Aktivasi GLUT4.}

Bukti terkini menunjukkan bahwa p38 mitogen-activated protein kinase (p38 MAPK) melanjutkan transpor glukosa tanpa mempengaruhi kemampuan GLUT4 untuk bertanslokasi ke permukaan membran sebagai respon terhadap insulin. Terdapat kemungkinan bahwa pada siklus translokasi GLUT4, GSVs tidak segera menuju kompartemen TGN namun memasuki kompartemen lain terlebih dahulu. Selain meningkatkan aktivitas p38 MAPK, insulin juga menurunkan jumlah GLUT4 yang terfosforilasi pada membran plasma. ${ }^{12}$

\section{BAHASAN}

Pemahaman siklus translokasi GLUT4 mengungkapkan beberapa fungsi GLUT4 normal pada tingkat molekular yaitu sebagai transporter spesifik substrat glukosa transmembran (transpor glukosa fasilitatif); meregulasi ambilan glukosa untuk metabolisme sel adiposa; mempertahankan homeostasis glukosa dengan menarik glukosa masuk kedalam sel adiposa; dan sebagai simporter yang menjaga glukosa agar tetap berada dalam sitosol sel adiposa.

Berdasarkan pada lokasi disfungsi GLUT4, maka dibedakan atas disfungsi primer GLUT4 dan disfungsi kaskade sinyal insulin. Telah diketahui bahwa keduanya dapat menimbulkan resistensi insulin yang berkomplikasi luas, namun mekanisme yang tepat belum diketahui. ${ }^{3,16}$

Disfungsi primer GLUT4 dapat berupa mutasi GLUT4 sehingga transpor glukosa transmembran plasma berkurang. Secara teoritis mutasi pada GLUT4 dapat menyebabkan resistensi insulin. Namun, polimorfisme gen GLUT4 sangat jarang ditemukan pada pengidap DMT2, dan memiliki prevalensi yang sama dengan subjek non diabetik. $^{3}$

Selain itu perubahan spesifik jaringan 
dalam produksi GLUT4 turut berperan. Ternyata konsentrasi GLUT4 dalam jaringan adiposa berkurang pada obesitas, gangguan toleransi glukosa atau DMT2, namun tidak demikian halnya pada jaringan otot rangka dengan keadaan yang sama. Selain itu berkurangnya produksi GLUT4 otot rangka pada penuaan subjek normal berperan penting dalam menurunnya kepekaan insulin. ${ }^{3}$

Disfungsi sinyal insulin dapat berupa defek pada translokasi GLUT4 intrasel dan defek kaskade sinyal insulin. Pada konsentrasi GLUT4 yang normal, terjadinya resistensi insulin diakibatkan defek pada lintasan sinyal insulin yang meregulasi translokasi GLUT4 atau pada perangkat molekular yang terlibat secara langsung dalam rekrutmen vesikel GLUT4 menuju membran plasma, mulai dari eksositosis, docking dan fusi, serta endositosis. 3,16

Defek kaskade sinyal insulin terutama pada sekuens aktivasi PI3K, karena konsentrasi reseptor insulin terfosforilasi dan IRS1 juga menurun pada otot rangka dan jaringan adiposa pada subjek dengan obesitas dan DMT2. Ekspresi dan aktivitas beberapa protein tirosin fosfatase meningkat pada jaringan otot rangka dan adiposa, namun tidak pada DMT2. Selain itu substrat $15 \mathrm{kDa}$ dari PKC menunjukkan ekspresi berlebihan pada jaringan target insulin pada pengidap DMT2. Ekspresi berlebihan Rad (protein pengikat GTP) juga menghambat translokasi GLUT4 pada kultur sel. Vanadate, yang menghambat fosfatase tirosin, menstimulasi transpor glukosa dengan meningkatkan translokasi GLUT4 sel jaringan otot dan adiposa. 3

Gangguan transpor glukosa oleh faktor sirkulasi atau parakrin dapat disebabkan oleh antara lain asam lemak bebas, glukosa, tumor necrosis factor- $\alpha$ (TNF- $\alpha)$ dan interleukin-6 (IL-6). 3,17,18

Pada manusia, infus lipid selama empat jam menurunkan ambilan glukosa yang terstimulasi insulin kedalam jaringan otot rangka akibat hilangnya kemampuan insulin untuk menstimulasi aktivitas PI3K. Defek dalam sinyal insulin dapat disebabkan oleh terinduksi asam lemak bebas dalam lintasan heksosamin. ${ }^{3,17}$

Toksisitas glukosa dapat melibatkan lintasan heksosamin, dimana enzim glutamin fruktosa-6 fosfat amidotransferase mengubah glukosa dari lintasan glikolitik, menghasilkan produksi glukosamin-6-fosfat dan produk heksosamin lainnya. Meningkatnya enzim ini menurunkan efek stimulasi insulin terhadap transpor glukosa dan translokasi Glut4 pada pengidap diabetes, hal ini mungkin berkaitan dengan terjadinya resistensi insulin. ${ }^{3}$

TNF- $\alpha$ memiliki efek inhibisi pada sinyal insulin dalam isolat jaringan adiposa dan otot. Tingginya ekspresi TNF- $\alpha$ pada jaringan adiposa dan otot pengidap obesitas dan diabetes menimbulkan hipotesis bahwa hal ini dapat menyebabkan resistensi insulin in vivo. Pada hewan coba (tikus Zucker $\mathrm{fa} / \mathrm{fa}$ ) pemberian antibodi monoklonal sistemik yang menetralkan TNF- $\alpha$ dapat memperbaiki resistensi insulin, namun tidak demikian pada pengidap DMT2., ${ }^{3,18}$

IL-6 dikaitkan dengan resistensi insulin, massa jaringan adiposa dan asam lemak bebas plasma. Peningkatan asam lemak bebas disebabkan karena IL-6 meningkatkan lipolisis trigliserida. Selain itu IL-6 juga menghambat produksi adiponektin; hal ini memperburuk keadaan resistensi insulin. ${ }^{17}$

Peran berbagai sitokin dan bahan lainnya terhadap kerja Glut4 pada jarngan adiposa masih memerlukan penelitian lanjut agar dapat diaplikasikan dalam pengobatan DMT2.

\section{SIMPULAN}

GLUT4 merupakan GLUT yang peka terhadap insulin. Dalam keadaan basal GLUT4 disekuestrasi di dalam sel jaringan adiposa sebagai vesikel bermembran lipid berlapis ganda. Glut4 diekspresi pada membran plasma dan organela dari jaringan adiposa dan memfasilitasi difusi pasif glukosa sirkulasi bila konsentrasi glukosa menurun pada jaringan tersebut.

Adanya gangguan ambilan glukosa oleh jaringan adiposa dapat mencetuskan resis- 
tensi insulin yang dapat disebabkan oleh primer pada GLUT4 (mutasi pada GLUT4 dan perubahan spesifik jaringan dalam produksi GLUT4), disfungsi sinyal insulin (defek pada translokasi GLUT intraselular dan defek kaskade sinyal insulin) dan gangguan transpor glukosa oleh faktor sirkulasi atau parakrin (asam lemak bebas, toksisitas glukosa dan lintasan heksosamin, TNF- $\alpha$, resistin dan Il-6).

\section{DAFTAR PUSTAKA}

1. Prentki M, Nolan CJ. Islet $\beta$ cells failure in type 2 diabetes. J Clin Inves. 2006; 116:1802.

2. Pessin JE, Thurmond DC, Elmendorf JS, Coker KJ, Okada S. Molecular basis of insulin-stimulated GLUT4 vesicle trafficking. J Biol Chem. 1999;274: 2593-6.

3. Shepherd PR dan Kahn BB. Glucose transporters and insulin action-Implications for insulin resistance and diabetes mellitus. NEJM 1999;341:248-57.

4. Masharani U, German MS. Greenspan's Basic \& Clinical Endocrinology (Eighth Edition). New York: McGraw Hill Companies, 2007.

5. Dugani CB, Klip A. Glucose transpoter 4: cycling, compartments and controversies. EMBO reports 2005;6(12):1137-42.

6. Cressey E. Understanding insulin. Performance and health on a whole new level. 2009 [cited 2009 Apr 12]. Available from: http://ericcressey.com/understanding-insulin

7. Murray RK, Granner DK, Mayes PA, Rodwell VW. Lipid transport and storage. Harper's Illustrated Biochemistry (Twenty seventh Edition). New York: McGraw Hill Professional, 2004.

8. Strobel P, Allard C, Perez-Acle T, Calderon $R$, Aldunate $R$, Leighton $F$. Myrycetin, quercetin and catechin-gallate inhibit glucose uptake in isolated rat adi- pocytes. Biochem J. 2005;386: 471-8.

9. Gould GW dan Holman GD. The glucose transporter family: Structure, function and tissue-specific expression. Biochem J. 1993;295,329-41.

10. Yu C, Cresswell J, Loffler MG, Bogan JS. The glucose transporter 4-regulating protein TUG is essential for highly insulinresponsive glucose uptake in 3T3-L1. $\mathrm{J}$ Biol Chem. 2007:282:7710-22.

11. McCarthy AM, Elmendorf JS. GLUT4's itinerary in health and disease. Indian $\mathbf{J}$ Med Res. 2007;125(3):373-88.

12. Watson RT, Kanzaki M dan Pessin JE. Regulated membrane trafficking of the insulin-responsive glucose transporter 4 in adipocytes. Endocrine Reviews 2004;25(2):177-204.

13. Houseknecht KL dan Kahn BB. Molecular mechanisms for insulin-stimulated glucose transport: Regulation of GLUT4 translocation. J Anim Sci. 1997;75(2):32-45.

14. Heyward CA, Pettitt TR, Leney SE, Welsh GI, Tavare JM, Wakelam MJO. An intracellular motif of GLUT4 regulates fusion of GLUT4-containing vesicles. BMC Cell Biol 2008:9;25.

15. Yang B, Sleegmaier M, Gonzales LC, Scheller RH. NSec1 binds a closed conformation of syntaxin1a. JCB 2000:148(2);247-52.

16. Buse JB, Yasuda K, Lay TP et al. Human GLUT4/muscle-fat glucose-transporter gene: Characterization and genetic variation. Diabetes 1992;41:1436-46.

17. Yu YH dan Ginsberg HN. Adipocyte signaling and lipid homeostasis: Sequelae of insulin-resistant adipose tissue. Circ Res 2005;96:1042-52.

18. Fonsena-Alaniz MH, Takada J, AlonsoVale MIC, Lima FB. Adipose tissue as an endocrine organ: from theory to practice. Jornal de Pediatria 2007;83(5): S193-203. 